\title{
ANALISIS DISKRIMINAN DALAM MEMPREDIKSI KINERJA PERBANKAN DI INDONESIA
}

\author{
Sumarlin', Annisa Juniarta Musda², Alim Syariati ${ }^{3}$ \\ ${ }^{1}$ Accounting Department, UIN Alauddin Makassar Alauddin Makassar, Indonesia. \\ E-mail:sumarlin@uin-alauddin.ac.id \\ 2Management Department, UIN Alauddin Makassar Alauddin Makassar, Indonesia. \\ E-mail:90200114065@uin-alauddin.ac.id \\ ${ }^{3}$ Management Department, UIN Alauddin Makassar Alauddin Makassar, Indonesia. \\ E-mail:alim.syariati@uin-alauddin.ac.id
}

\begin{tabular}{|c|c|}
\hline ARTICLE INFO & ABSTRACT \\
\hline $\begin{array}{l}\text { Keywords : } \\
\text { Bank Performance, Prediction, } \\
\text { Discriminant Analysis, Rasio Keuangan } \\
\text { How to cite: } \\
\text { Sumarlin., Musda, Annisa Juniarta., } \\
\text { Syariati, Alim. (2019). Analisis } \\
\text { Diskriminan dalam Memprediksi Kinerja } \\
\text { Perbankan di Indonesia. JMM UNRAM, } 8 \\
\text { (3), } 225-233 \\
\text { DOI: } \\
\text { http://dx.doi.org/10.29303/jmm.v8i3 }\end{array}$ & $\begin{array}{l}\text { This study aims to determine the contribution of } \\
\text { financial ratios into the classification of banks' } \\
\text { performance into good, fairly good and less good by } \\
\text { using discriminant analysis. This research is } \\
\text { quantitative with data amounted from } 34 \text { banks. The } \\
\text { results of five banking financial ratios that can } \\
\text { distinguish the status of the banking performance level } \\
\text { are CAR, ROA, BOPO, and NPL. The first equation to } \\
\text { predict differences in banking groups is Non- } \\
\text { Performing Loan and Secondly is ROA. } \\
\text { Penelitian ini bertujuan untuk menginvestigasi } \\
\text { kontribusi unik dari rasio keuangan dalam } \\
\text { mengklasifikasi kinerja bank menjadi kriteria } \\
\text { baik, cukup baik, ataupun kurang baik dengan } \\
\text { menggunakan analisis diskriminan. Penelitian } \\
\text { kuantitatif ini menggunakan data dari } 34 \text { bank. } \\
\text { Hasil penelitian mendapati dari lima rasio } \\
\text { keuangan yang bisa membedakan kinerja } \\
\text { keuangan yaitu, CAR, ROA, BOPO, dan NPL. } \\
\text { Persamaan yang mampu memprediksi kinerja } \\
\text { bank terbaik adalah NPL, dan disusul oleh ROA. }\end{array}$ \\
\hline & $\begin{array}{l}\text { Copyright } @ 2019 \text { JMM UNRAM. All rights } \\
\text { reserved. }\end{array}$ \\
\hline
\end{tabular}

\section{PENDAHULUAN}

Pada periode 1982-1988 sistem finansial Indonesia didominasi perbankan, terutama bank komersial milik pemerintah. Peran penting bank swasta nasional meningkat pada tahun 1988-1991 yang memfokuskan kepada upaya penurunan hambatan dalam memasuki pasar dan penawaran yang menarik seperti bank komersial milik pemerintah. Hal tersebut ditandai dengan terbentuknya 40 bank swasta baru dan 15 bank patungan. Komposisi 
penguasaan pangsa pasar berubah begitu memasuki tahun 1998 menyusul dikeluarkannya kebijakan pemerintah yang melikuidasi 16 bank swasta nasional pada bulan November 1997 akibat krisis moneter. Kepercayaan masyarakat menurun drastis akibat dari likudidasi terhadap bank-bank swasta nasional. Hal ini ditandai dengan penarikan dana masyarakat secara besar-besaran (bank rush) dari swasta ke nasional.

Bank sebagai lembaga yang berperan sebagai perantara keuangan (financialintermediary) antara pihak-pihak yang memiliki dana (surplus unit) dengan pihak- pihak yangmemerlukan dana (deficit unit) serta sebagai lembaga yang berfungsi memperlancar aliran lalu lintas pembayaran. Disamping itu, bank juga sebagai suatu industri yang dalam kegiatan usahanya mengandalkan kepercayaan masyarakat dalam setiap kegiatannya, masyarakat yang percaya dengan bank akan lebih mudah menyimpan dana lebihnya kepada bank sehingga harusnya tingkat kesehatan perlu dipelihara. (Merkusiwati, 2007;100).

Perusahaan perbankan dituntut menjadi lebih dinamis dalam berbagai hal termasuk meningkatkan kemampuan pelayanan dalam meraih kepercayaan masyarakat. Langkah strategis yang dapat dilakukan adalah dengan cara memperbaiki kinerja bank. Kinerja bank dapat dinilai dari beberapa indikator, salah satu indikator utama yang dijadikan dasar penilaian adalah laporan keuangan bank yang bersangkutan. Laporan keuangan dapat memberikan informasi kepada pihak diluar bank, misalnya bank sentral, masyarakat umum, dan investor mengenai gambaran umum posisi keuangannya Selain itu, analisis rasio juga membantu manajemen dalam memahami apa yang sebenarnya terjadi pada perbankan berdasarkan suatu informasi laporan keuangan baik dengan perbandingan rasio-rasio sekarang dengan yang lalu dan yang akan datang pada internal perbankan maupun perbandingan rasio perbankan dengan perbankan lainnya (Munawir 2008).Karenanya, penelitian ini bertujuanuntuk mengetahui kontribusi rasio keuangan Biaya Operasionalterhadap Pendapatan Operasional (BOPO), Non Performing Loan (NPL), Capital Adequacy Ratio (CAR), Loan To Deposit Ratio (LDR) dan Return On Assets (ROA) dalammengelompokkan bank dalam kategori berkinerja baik, cukup baik dan berkinerja kurang baik dengan menggunakan analisis diskriminan.

\section{TINJAUAN PUSTAKA}

\subsection{Signaling Theory}

Isyarat atau sinyal dapat diartikan sebagai suatu tindakan strategis perusahaan yang bertujuan untuk memberikan petunjuk bagi investor mengenai pandangan manajemen terhadap prospek perusahaan. Sinyal ini dapat berbentuk sebagai sebuah informasi tentang apa yang sudah dilakukan oleh pihak manajemen mengenai tindakan yang sudah dilakukan pihak manajemen itu sendiri dalam rangka untuk merealisasikan keinginan pemilik. Informasi memengaruhi keputusan akan investasi oleh pihak eksternal, sehingga informasi yang dikeluarkan perusahaan merupakan sesuatu yang penting adanya. Informasi tersebut penting bagi berbagai pihak, dalam hal ini investor dan pelaku bisnis karena informasi memberikan keterangan atas catatan atau gambaran keadaan perusahaan, baik untuk keadaan masa lalu, keadaan sekarang maupun keadaan masa depan bagi kelangsungan hidup perusahaan dan bagaimana efeknya bagi perusahaan (Brigham dan Houston, 2001: 36).

Secara garis besar signaling theory erat kaitannya dengan ketersediaan informasi laporan keuangan. Laporan keuangan dapat digunakan untuk mengambil keputusan bagi para investor, laporan keuangan merupakan bagian terpenting dari analisis fundamental perusahaan. Pemeringkatan perusahaan yang telah go public lazimnya didasarkan pada 
analisis rasio keuangan ini. Analisis ini dilakukan untuk mempermudah interpresasi terhadap laporan keuangan yang telah disajikan oleh manajemen (Kretarto, 2001: 53).

\subsection{Kinerja Bank}

Kamus Besar Bahasa Indonesia mendefinisikan kinerja (performance) adalah sesuatu yang dicapai atau prestasi yang diperlihatkan. Kinerja keuangan dapat diukur dengan efisensi, sedangkan efisiensi bisa diartikan rasio perbandingan antara pemasukan dan pengeluaran. Dengan pengeluaran biaya tertentu diharapkan memeroleh hasil yang optimal atau dengan hasil tertentu diharapkan mengeluarkan biaya seminimal mungkin. Kinerja keuangan perusahaan diukur dari efisiensinya diproksikan dengan beberapa tolak ukur yang tercermin di dalam keuangan (Machfoedz, 1999).

Informasi kinerja perusahaan terutama profitabilitas diperlukan untuk menilai perubahan potensi sumberdaya ekonomi yang mungkin dikendalikan di masa depan. Informasi fluktuasi kinerja bermanfaat untuk memprediksi kapasitas perusahaan dalam menghasilkan arus kas dari sumberdaya yang ada, disamping itu informasi tersebut juga berguna dalam perumusan pertimbangan tentang efektifitas perusahaan dalam memanfaatkan sumberdaya (IAI, 2001). Ukuran kinerja keuangan bank yang akan digunakan dalam penelitian ini adalah sebagai berikut (Syariati, 2012) :

2.2.1. Biaya Operasional terhadap Pendapatan Operasional (BOPO)

Rasio Biaya Operasional terhadap Pendapatan Operasioanl (BOPO) sering disebut sebagai rasio efisiensi yang digunakan untuk mengukur kemampuan manajemen bank dalam mengendalikan biaya operasioanal terhadap pendapatan operasional. Semakin kecil rasio ini berarti semakin efisien biaya operasional yang dikeluarkan bank yang bersangkutan (Almilia dan Herdiningtyas, 2005). Bank Indonesia menetapkan angka terbaik untuk rasio BOPO adalah dibawah 90\%, karena jika rasio BOPO melebihi $90 \%$ hingga mendekati angka $100 \%$ maka bank tersebut dapat dikategorikan tidak efisien dalam menjalankan operasinya.

2.2.2. Non Performing Loan (NPL)

Salah satu risiko usaha bank menurut Peraturan Bank Indonesia adalah risiko kredit, yang didefiniskan sebagai risiko yang timbul sebagai akibat kegagalan counter party memenuhi kewajiban. Risiko kredit merupakan risiko yang dihadapi bank karena menyalurkan dananya dalam bentuk pinjaman kepada masyarakat. Rasio keuangan yang digunakan sebagai proksi terhadap nilai suatu risiko kredit adalah rasio Non Performing Loan (NPL). Rasio ini menunjukkan bahwa kemampuan manajemen bank dalam mengelola kredit bermasalah yang diberikan oleh bank.

2.2.3. Capital Aqeduacy Ratio (CAR)

Permodalan (capital adequacy) menunjukkan kemampuan bank dalam mempertahankan modal yang mencukupi dan kemampuan manajemen bank dalam mengidentifkasi, mengawasi dan mengontrol risiko-risiko yang timbul yang dapat berpengaruh terhadap besarnya modal bank. Capital Adequacy Ratio (CAR) digunakan untuk menilai keamanan dan kesehatan bank dari sisi modal untuk atau untuk mengukur kecukupan modal yang dimiliki bank untuk menunjang aktiva yang mengandung risiko (Dendawijaya, 2009:121). Sejalan dengan standar yang ditetapkan Bank of International Setttlements (BIS), seluruh bank yang ada di Indonesia diwajibkan untuk menyediakan modal minimum sebesar $8 \%$ dari ATMR (Kuncoro dan Suhardjono, 2002).

2.2.4. Loan to Deposit Ratio (LDR)

Perhitungan likuiditas bank digunakan untuk mengukur kemampuan bank dalam memenuhi kewajiban jangka pendeknya pada saat ditagih (Kasmir, 2013:221). Analisis likuditas dalam penelitian ini diukur dengan rasio Loan to Deposit Ratio (LDR) atau Finance to Deposit Ratio (FDR) untuk bank syariah. FDR menyatakan seberapa jauh kemampuan 
bank dalam membayar kembali penarikan dana yang dilakukan deposan dengan mengandalkan pembiayaan sebagai sumber likuiditasnya.

2.2.5. Return On Asset (ROA)

Dalam penentuan tingkat kesehatan bank, Bank Indonesia lebih mementingkan penilaian besarnya ROA. Hal ini dikarenakan Bank Indonesia sebagai pembina dan pengawas perbankan lebih mengutamakan nilai rentabilitas (profitabilitas) suatu bank yang diukur dengan asset yang dananya sebagian besar berasal dari masyarakat. Semakin besar ROA suatu bank, semakin besar pula tingkat yang dicapai suatu bank, dan semakin baik pula posisi bank dari segi penggunaan aset (Dendawijaya, 2009: 119).

Dalam rangka memahami Biaya Operasional terhadap Pendapatan Operasional (BOPO), Non Performing Loan (NPL), Capital Adequacy Ratio (CAR), Loan to Deposit Ratio (LDR) dan Return On Assets (ROA), maka digunakan konsep teori Basel II menurut Basel Committee on Banking Supervision (BCBS) sebagai aturan tentang penguatan modal dan likuiditas perbankan global yang berfungsi sebagai shock absor berbagi perbankan untuk menghadapi krisis keuangan dan tekanan ekonomi.

\section{METODE PENELITIAN}

Jenis penelitian ini adalah penelitian dengan menggunakan metode kuantitatif. Lokasi penelitian dilakukan di Bursa Efek Indonesia (BEI) pada periode 2015-2016. Dipilihnya BEI sebagai tempat penelitian karena BEI merupakan bursa pertama di Indonesia, yang dianggap memiliki data yang lengkap mengenai laporan keuangan perbankan dan telah terorganisir dengan baik. Penelitian ini menggunakan pendekatan deskriptif dengan metode penelitian analisis diskriminan. Analisis diskriminan dapat digunakan untuk mengklasifikasikan atau mengelompokkan suatu individu kedalam kelompok dari dua kelompok atau lebih. Suatu fungsi diksriminan dapat dikatakan layak untuk dibentuk bilater dapat perbedaan nilai rataan di antara kelompok-kelompok yang ada (Johnson dan Wichern, 2007). Populasi yang digunakan dalam peneltian ini adalah bank umum yang terdaftar di Bursa Efek Indonesia periode 2015-2016. Adapun teknik yang digunakan dalam penentuan sampling adalah dengan menggunakan teknik purposive sampling. Berdasarkan kriteria yang telah ditentukan terdapat 34 perusahan perbankan yang dapat dijadikan sampel dalam penelitian ini. Teknik analisis data dalam penelitian ini menggunakan analisis diskriminan untuk memeroleh gambaran tentang prediksi kinerja perbankan dengan menggunakan SPSS. 


\section{HASIL DAN PEMBAHASAN}

\subsection{Uji Asumsi Klasik}

4.1.1. Uji Normalitas

\begin{tabular}{|l|l|r|}
\hline \multicolumn{2}{|c|}{ One-Sample Kolmogorov - Smirnov Test } \\
\hline $\mathbf{2}$ & Unstandardized Residual \\
\hline N & Mean & .0000000 \\
\hline \multirow{2}{|l|}{} & $\begin{array}{l}\text { Std. } \\
\text { Normal Parameters }{ }^{\mathrm{a}, \mathrm{b}}\end{array}$ & .45324721 \\
\hline \multirow{2}{*}{$\begin{array}{l}\text { Most Extreme } \\
\text { Differences }\end{array}$} & Absolute & .159 \\
\cline { 2 - 4 } & Positive & .159 \\
\cline { 2 - 3 } & Negative & -.088 \\
\hline Kolmogorov-Smirnov Z & & 1.307 \\
\hline Asymp. Sig. (2-tailed) & & .166 \\
\hline
\end{tabular}

Sumber : Data yang diolah dengan SPSS

Hasil dari uji normalitas diperoleh semua variabel memiliki nilai Sig. lebih dari 0.05 artinya variabel bebas tersebut berdistribusi normal, sehingga variabel-variabel bebas tersebut memenuhi asumsi dan dapat digunakan untuk analisis dikriminan.

4.1.2. Uji Homogenitas (Matrik Kovarian)

\begin{tabular}{|c|c|c|}
\hline \multicolumn{3}{|c|}{ Test Resultsa } \\
\hline \multicolumn{2}{|c|}{ Box's M } & 328.232 \\
\hline \multirow{4}{*}{$\mathrm{F}$} & Approx. & 26.453 \\
\hline & df1 & 10 \\
\hline & df2 & 870.595 \\
\hline & Sig. & .000 \\
\hline
\end{tabular}

Sumber : Data yang diolah dengan SPSS

Hasil uji box's $M$ menunjukkan bahwa nilai F sebesar 26.453 dan signifikansi pada 0.000. Probabilitas ini di bawah 0.05 maka dapat disimpulkan bahwa matrice covariance antar grup memang berbeda dalam hal ini menyalahi asumsi diskriminan. Namun demikian analisis fungsi diskriminan tetap robust walaupun asumsi homogenitas varians tidak terpenuhi dengan syarat data tidak memiliki outlier (Ghozali, 2008).

4.1.3. Uji Multikolineritas

\begin{tabular}{|l|l|l|l|l|l|}
\hline \multicolumn{7}{|c|}{ Tests of Equality of Group Means } \\
\hline & $\begin{array}{c}\text { Wilks' } \\
\text { Lambda }\end{array}$ & \multicolumn{1}{|c|}{$\mathrm{F}$} & $\mathrm{df1}$ & $\mathrm{df2}$ & Sig. \\
\hline CAR & .895 & 3.815 & 2 & 65 & .027 \\
\hline ROA & .743 & 11.270 & 2 & 65 & .000 \\
\hline BOPO & .531 & 28.685 & 2 & 65 & .000 \\
\hline LDR & .993 & .214 & 2 & 65 & .808 \\
\hline NPL & .543 & 27.332 & 2 & 65 & .000 \\
\hline
\end{tabular}

Sumber : Data yang diolah dengan SPSS

Dari ke 5 variabel tersebut, terdapat 4 variabel berbeda secara signifikan untuk dua grup diskriminan, yaitu CAR, ROA, BOPO dan NPL. Dengan demikian pembagian kelompok kinerja bank dipengaruhi oleh variabel-variabel tersebut. 


\subsection{Analisis Diskriminan}

Untuk mengetahui variabel mana saja yang dapat dimasukkan dalam fungsi diskriminan maka perlu melakukan metode analisis stepwise, yang dilakukan dengan cara memasukkan variabel satu persatu ke dalam model diskriminan, yang memungkinkan satu atau lebih variabel independent untuk dibuang dari model, tergantung tingkat signifikansi dari hasil pengujian yang diperoleh.

Variables in the Analysis

\begin{tabular}{|l|l|c|c|c|c|}
\hline \multicolumn{2}{|c|}{ Step } & Tolerance & $\begin{array}{c}\text { Sig. of F } \\
\text { to Remove }\end{array}$ & $\begin{array}{c}\text { Min. D } \\
\text { Squared }\end{array}$ & Between Groups \\
\hline 1 & ROA & 1.000 & .000 & & \\
\hline 2 & ROA & .986 & .000 & .023 & 2.00 and 3.00 \\
\cline { 2 - 6 } & BOPO & .986 & .000 & 1.731 & 1.00 and 2.00 \\
\hline \multirow{3}{*}{3} & ROA & .963 & .000 & 2.041 & 2.00 and 3.00 \\
\cline { 2 - 6 } & BOPO & .977 & .000 & 1.865 & 1.00 and 3.00 \\
\cline { 2 - 6 } & CAR & .964 & .010 & 6.101 & 1.00 and 2.00 \\
\hline \multirow{3}{*}{4} & ROA & .961 & .000 & 2.129 & 2.00 and 3.00 \\
\cline { 2 - 6 } & BOPO & .671 & .020 & 8.759 & 1.00 and 3.00 \\
\cline { 2 - 6 } & CAR & .938 & .007 & 6.561 & 1.00 and 2.00 \\
\cline { 2 - 6 } & NPL & .650 & .018 & 8.350 & 1.00 and 3.00 \\
\hline
\end{tabular}

Sumber : Data yang diolah dengan SPSS

Hasil stepwise variabel yang signifikan ada 4 yaitu ROA, BOPO, CAR dan NPL. Variabel ini mampu membedakan kinerja perbankan berdasarkan pada nilai Wilk's lambda dan nilai minimum mahalanlobis distance. Ukuran keeratan hubungan antara discriminant score dengan pengkategorian kinerja bank dapat dilihat pada nilai canonical correlation.

Eigenvalues

\begin{tabular}{|l|r|r|r|r|}
\hline Function & Eigenvalue & $\begin{array}{c}\text { \% of } \\
\text { Variance }\end{array}$ & $\begin{array}{r}\text { Cumulative } \\
\%\end{array}$ & $\begin{array}{r}\text { Canonical } \\
\text { Correlation }\end{array}$ \\
\hline 1 & $1.352^{\mathrm{a}}$ & 75.7 & 75.7 & .758 \\
2 & $.434^{\mathrm{a}}$ & 24.3 & 100.0 & .550 \\
\hline
\end{tabular}

Sumber : Data yang diolah dengan SPSS

Diketahui nilai korelasi kanonikal fungsi diskriminan 1 sebesar 0.758 . Apabila di kaudratkan $(0.758)^{2}=0.574$, maka dapat disimpulkan bahwa 57\% variabel kolektibilitas yang mampu menjelaskan variasi, sedangkan nilai korelasi kanonikal fungsi diskriminan 2 sebesar 0.758. Apabila di kaudratkan $(0.550)^{2}=0.302$, maka dapat disimpulkan bahwa hanya $30 \%$ variabel kolektibilitas yang mampu menjelaskan variasi. 


Canonical Discriminant
Function Coefficients
\begin{tabular}{|c|c|c|}
\hline \multirow{2}{*}{} & \multicolumn{2}{|c|}{ Function } \\
\cline { 2 - 3 } & 1 & 2 \\
\hline CAR & -.046 & -.137 \\
\hline ROA & -.210 & .481 \\
\hline BOPO & .027 & .009 \\
\hline NPL & .317 & .009 \\
\hline (Constant) & -2.339 & 1.085 \\
\hline
\end{tabular}

Sumber : Data yang diolah dengan SPSS

Persamaan estimasi fungsi diskriminan unstandardized dapat membuat persamaan fungsi diskriminan $Z_{1}=-2.229+(-0.046) \mathrm{CAR}+(-0.210) \mathrm{ROA}+0.027 \mathrm{BOPO}+0.317 \mathrm{NPL}$. Fungsi $Z_{1}$ merupakan fungsi diskriminan pertama yang memprediksi pengkategorian antara kinerja bank baik dan cukup baik. Sedangkan berdasarkan fungsi 2 diperoleh $Z_{2}=$ $1.085+(-0.137) \mathrm{CAR}+0.481 \mathrm{ROA}+0.009 \mathrm{BOPO}+0.009 \mathrm{NPL}$. Fungsi $\mathrm{Z}_{2}$ merupakan fungsi diskriminan ke dua yang memprediksi pengkategorian antara kinerja bank cukup baik dan kurang baik.

Jika kasus menggunakan tiga kode yang menghasilkan dua fungsi diksriminan, cara memilah dengan menetapkan Zcu menjadi sangat kompleks. Untuk itu, pada kasus dengan lebih dari dua kode, penggunaan territorial map akan lebih efektif untuk menentukan penempatan sebuah data pada kode (tipe) tertentu. Territorial map pada dasarnya memetakan (maping) batas-batas setiap kode berdasar sumbu X (fungsi diskriminan 1) dan sumbu Y (fungsi diskriminan 2).

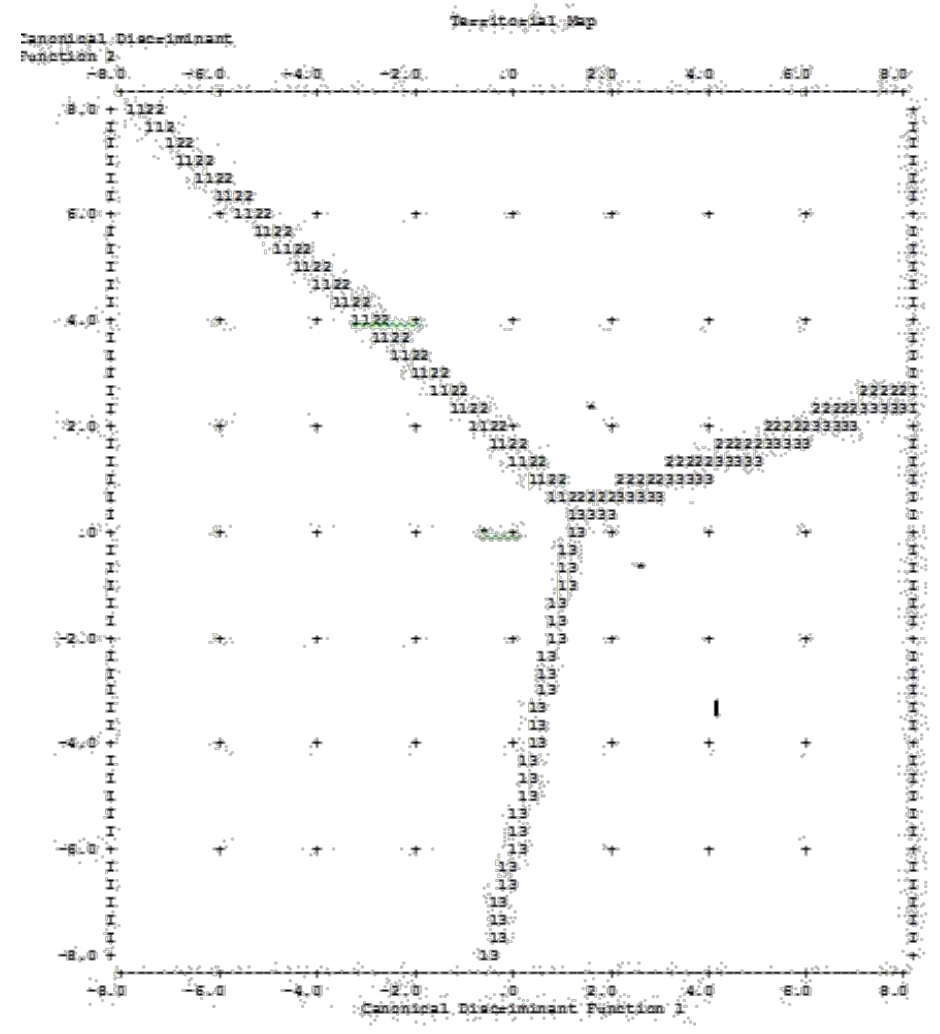

Gambar 1. Teritorial Map

Sumber : Data olah SPSS 
Jika dilihat pada map di atas, terlihat 3 grup dari kiri ke kakan berdasarkan kinerja bank yang telah disesuaikan dengan sumbu $X$ dan $Y$ fungsi diskriminan. Dengan demikian bank dengan kinerja baik berada pada posisi kiri territorial map, bank dengan kinerja cukup baik berada pada posisi tengah atas territorial map dan bank dengan kinerja kurang baik berada pada posisi kanan territorial map.

\subsection{Pembahasan}

4.3.1. Analisis diskriminan kinerja bank berdasarkan variabel pembeda

Berdasarkan hasil pengujian dengan menggunakan metode analisis stepwise, untuk memprediksi kinerja perbankan, maka dapat disimpulkan bahwa variabel independen yang terdiri dari ROA, BOPO, CAR dan NPL merupakan merupakan variabel yang dapat dijadikan variabel prediktor dengan nilai signifikansi bernilai $<0,05$. Hasil ini secara meyakinkan menunjukkan bahwa dari lima variabel rasio keuangan yang dianalisis dengan analisis diskriminan stepwise, hanya memilih 4 rasio, dan menyimpulkan Loan to Deposit Ratio tidak mampu menjadi pembeda yang signifikan dalam kinerja keuangan bank di Indonesia. Nampaknya, struktur modal perbankan di Indonesia yang sudah mapan dan belajar banyak dari guncangan-guncangan krisis tahun 1998 dan 2008, membuat bank sudah lebih siap dalam menjaga keseimbangan antara utang dan tabungan. Kemampuan bank menjaga jumlah dana pihak ketiga (DPK) menjadi alasan stabilnya tingkat struktur modal bank.

\subsubsection{Analisis diskriminan kinerja bank berdasarkan variabel faktor dominan}

Penelitian ini selain untuk menentukan variabel-variabel independen yang menjadi faktor pembeda, juga bertujuan untuk membuktikan terdapat variabel yang merupakan faktor paling dominan dari variabel-variabel penelitian yang membedakan status tingkat kinerja bank. Persamaan estimasi fungsi diskriminan unstandardized dapat membuat dua persamaan fungsi diskriminan. Dari persamaan diskriminan $1\left(Z_{1}\right)$, terlihat bahwa nilai rata-rata rasio yang paling dominan untuk memprediksi perbedaaan kelompok perbankan adalah NPL. Pada persamaan diskriminan $2\left(Z_{2}\right)$, terlihat bahwa nilai rata-rata rasio yang paling dominan untuk memprediksi perbedaan kelompok adalah ROA.

\section{KESIMPULAN}

Dalam penelitian ini variabel CAR, ROA, BOPO dan NPL merupakan variabel pembeda yang mampu membedakan perusahaan berkinerja baik, cukup baik dan kurang baik. Karena diketahui variabel tersebut mempunyai nilai F dibawah Sig. 0.05 (Imam Ghozali, 2006). Dari persamaan diskriminan 1 (Z1), terlihat bahwa nilai rata-rata rasio yang paling dominan untuk memprediksi perbedaaan kelompok perbankan adalah NPL. Pada persamaan diskriminan 2 (Z2), terlihat bahwa nilai rata-rata rasio yang paling dominan untuk memprediksi perbedaan kelompok adalah ROA. Kepada pihak perusahaan perbankan yang masuk dalam pengkategorian bank kurang sehat

untuk melakukan tindak lanjut perbaikan kesehatan bank dengan analisis kas untuk saat ini atau masa mendatang. Diharapkan bagi pihak perusahaan yang berkinerja baik mewaspadai perkembangan dan pertumbuhan ekonomi serta ancaman lingkungan bisnis. Diharapkan pada peneliti selanjutnya agar dipertimbangkan kembali rasio-rasio keuangan lain sebagai alat bantu untuk mengukur kinerja perbankan yang dapat dijadikan variabel penelitian. 


\section{DAFTAR PUSTAKA}

Brigham, E. F., \& Houston, J. F. (2012). Fundamentals of financial management. Cengage Learning.

Dendawjaya, L. (2009). Manajemen Perbankan. Jakarta : Ghalia Indonesia.

IAI. (2009). Standar Akuntansi Keuangan. Jakarta: Salemba Empat. Kepatuhan. Jakarta : Grafiti Pers.

Kretarto, A.(2001). Investor Relation: Pemasaran dan Komunikasi Keuangan Perusahaan Berbasis Machfoedz, M.(1999). Akuntansi Manajemen 2. Edisi 3. Yogyakarta : BPFE. 1999 Merkusiwati, N.K. L.A. (2007). Evaluasi Pengaruh Camel Terhadap Kinerja Perusahaan. Munawir. Analisis Laporan Keuangan.(2008). Edisi Keempat. Yogyakarta : Liberty Syariati, A. (2012). The Effect Of Islamic Commercial Banks' health And Their Cost Of Fund Upon Its Financing In Indonesia Over 2005-2009. Proceeding of International Conference of AIMI Indonesia. 